\title{
Mirar a las aves mirar... y hacer (arte)
}

\author{
Concepción Cortés Zulueta \\ Universidad de Málaga \\ ccorteszulueta@uma.es
}

RESUMEN: Mirar a los (demás) animales es una actividad humana muy extendida, sea en un sentido más tangible, o más conceptual, como por ejemplo hace W. J. T. Mitchell en su ensayo Illusion: Looking at Animals Looking. Según una de las conclusiones y propuestas de este autor, quizás tendríamos que volver a aprender cómo mirar a los animales. Tal y como llevan décadas haciendo los estudios animales, este artículo se acerca a las perspectivas de estos, y en concreto, de las aves, para tratar de considerarlos en sus propios términos, más allá de los términos humanos. Para ello, reúne una serie de historias mediante las cuales dialoga con el texto y la estructura planteada por Mitchell no solo para mirar a las aves mirar, sino también ejercer su agencia, y hacer. Incluso ilusionismo, y arte, desdibujando con ello los límites entre animales humanos y no humanos.

PALABRAS CLAVE: Estudios animales; Aves; Golondrinas; W. J. T. Mitchell; Historias; Jakob von Uexküll; llusionismo.

\section{Looking at Birds Looking... and Making (Art)}

ABSTRACT: Looking at (other) animals is a widespread human activity, either in a more tangible or in a more conceptual sense as, for instance, W. J. T. Mitchell suggests in his essay Illusion: Looking at Animals Looking. According to one of the conclusions and proposals of this author, we may have to learn again how to look at animals. As animal studies have been doing for decades now, this article approaches the perspectives of non-human animals, and specifically, of birds, to try to consider them on their own terms, beyond human ones. In order to do this, it gathers a series of stories through which it dialogues with Mitchell's text and structure not just to look at birds looking, but also to look at birds exercising their agency, and making. Even illusionism and art, thus blurring the boundaries between human and non-human animals.

KEYWORDS: Animal studies; Birds; Swallows; W. J. T. Mitchell; Stories; Jakob von Uexküll; Illusionism.

«Como figuras en escenas de intercambio visual, los animales tienen una relación especial, casi mágica, con la humanidad»².

W. J. T. Mitchell, Illusion: Looking at Animals Looking

Esta misma mañana me he pasado a echarle un vistazo al progreso de un nido de golondrinas dáuricas, en construcción, que descubrí hace dos días. Sucedió porque, mientras sacaba a pasear a mi perro, vi a la pareja posarse en el suelo, en un recuadro ajardinado en el que el riego automático estaba encendido. Al detenerme a mirarlas, comprobé que aprovechaban que se habían formado algunos charquitos para recoger barro, y llevárselo volando, una y otra vez (pude incluso usar el móvil para grabar un vídeo del proceso, por si a alguien le interesa). Y decidí seguirlas.

Al igual que aviones y golondrinas comunes, las dáuricas construyen sus nidos apilando hileras de pequeñas pellas de barro, que mezclan con saliva y moldean con sus picos. Aunque, a diferencia de los de aviones y otras golondrinas, cuando el nido esté terminado no tendrá forma de medio tazón, más o menos abierto (golondrinas comunes) o cerrado (aviones ídem), adosado a una cornisa o esquina: será algo así como un «iglú invertido», una fracción de esfera de la que emerge un

Cómo citar este artículo: CORTÉS ZULUETA, Concepción, «Mirar a las aves mirar... y hacer (arte)», Boletín de Arte-UMA, n. ${ }^{\circ} 40$, Departamento de Historia del Arte, Universidad de Málaga, 2019, pp. 27-42, ISSN: 0211-8483, e-ISSN: 2695-415X, DOI: http://dx.doi.org/10.24310/ BoLArte.2019.v0i40.6642 
largo túnel. Eso, suponiendo que el nido en cuestión llegue a estar acabado. Al segundo día, por desgracia, «mis» goIondrinas habían tenido que empezar de cero. Dado que han elegido la entrada de una urbanización de costa, sumado al hecho de que el suelo estuviera casi limpio de restos de barro y deposiciones, es posible, puede que incluso probable, que alguien decidiera echar el nido abajo, para así tratar de expulsarlas.

Por el momento, el presunto intento de desahucio ha sido un fracaso. Esta mañana el nido estaba más avanzado que el segundo día, aunque menos que el primero, y la pareja de golondrinas dáuricas se turnaba para añadir más barro desde dentro del mismo. Mirar a las golondrinas hacer malabares con el viento para acertar en el nido, o junto a un charco, mientras ocasionalmente miran en tu dirección y sopesan tu presencia. Valorar que sean capaces de construir una forma y espacio tales con lo que hay disponible en el entorno, a mano (o más bien, pico), sin perturbarlo apenas. Leer la historia escrita en la sucesión de pellas de barro: cada una, un viaje; cada matiz de marrón, naranja, o gris un charco y un barro nuevo, porque el anterior se secó. Mirar a estas aves hacer...

«Otra [de las reglas] podría ser que tenemos que aprender una vez más cómo mirar a los animales».

W. J. T. Mitchell, Illusion: Looking at Animals Looking

Mirar a los (demás) animales es una actividad humana muy extendida, sea en un sentido más práctico y tangible o en otro más conceptual, y por lo tanto, más bien metafórico. Un ejemplo de lo primero somos quienes, a la mínima oportunidad, nos armamos de prismáticos para ver si detectamos alguna novedad entre los pájaros del barrio (actividad que apenas destacaría en ciertos países); o si, con un poco de suerte y dada la inmediatez del Mediterráneo, conseguimos observar aves marinas o incluso delfines, ya más en la lejanía. Por otro lado, en la vertiente conceptual se ubicarían textos o títulos como Why look at animals? de John Berger (1991 [1977]); libros como Through our eyes only? The search for animal consciousness de Marian Stamp Dawkins (1993), o Looking at animals in human history (2007), de Linda Kalof. O también Illusion: Looking at animals looking de W. J. T. Mitchell (1995), ensayo con el que pretendo dialogar en este artículo. llusión: mirar, o mirando, a los animales... mirar, según la posible traducción del título del capítulo de Mitchell, en el cual aborda una serie de historias con protagonistas animales (no humanos, sobreentiende el autor). Historias en torno a las que despliega las complejidades de los términos ilusión, e ilusionismo, asociando en sus tesis el primero con lo animal y lo natural, sensorial y biológico, y el segundo con lo humano y lo cultural, a la par que identificándolo como una práctica que, históricamente, se habría realizado o valorado para ciertos fines.

Mirar a las aves mirar (y hacer), especifico en mi títu$1 \mathrm{O}^{4}$. En primer lugar, por acotar el tema. Al tratarse algunos de los míos de animales un tanto más vivaces, el campo se vuelve demasiado amplio y diverso como para sopesarlos a todos (mamíferos, aves, reptiles, anfibios, peces, artrópodos, moluscos, crustáceos, anélidos, equinodermos y tantos otros) de un único y quizás excluyente plumazo. En continuidad con el hilo conductor de Mitchell he reunido aquí, a modo de historias, una serie de relatos y situaciones que quisiera encuadrar dentro de un desafío por parte de las aves hacia los mamíferos en general, y hacia primates y humanos en particular. De hecho, las aves ya no son consideradas cerebros de chorlito, y en los últimos años se han ido remediando los prejuicios y sesgos existentes en cuanto a su inteligencia y capacidades hasta llegar a equiparar algunos de sus logros (uso de herramientas, memoria episódica, quizás hasta teoría de la mente) con los de los primates (Emery, 2016; Marler, 1996). Después de todo, las aves son esos descendientes de dinosaurios con una historia evolutiva de decenas de millones de años que, entre otras cosas, nos recuerdan a diario nuestra incapacidad fisiológica de volar.

Para concluir, transitaré desde la acción de mirar a las aves mirar hacia la de mirar a las aves mirar y hacer, incluso arte. En parte porque es una manera de devolverles su agencia, la posibilidad de actuar y marcar la diferencia. $Y$ también porque, a pesar de ese fetichismo óptico que Mitchell detecta (1995: 343), y que estaría empeñado en elevar la visión por encima del resto de sentidos y en mantenerla en un plano más aséptico y conceptual, mirar y hacer no quedan tan lejos. Y diría que todavía menos en las aves, o en los demás animales. 


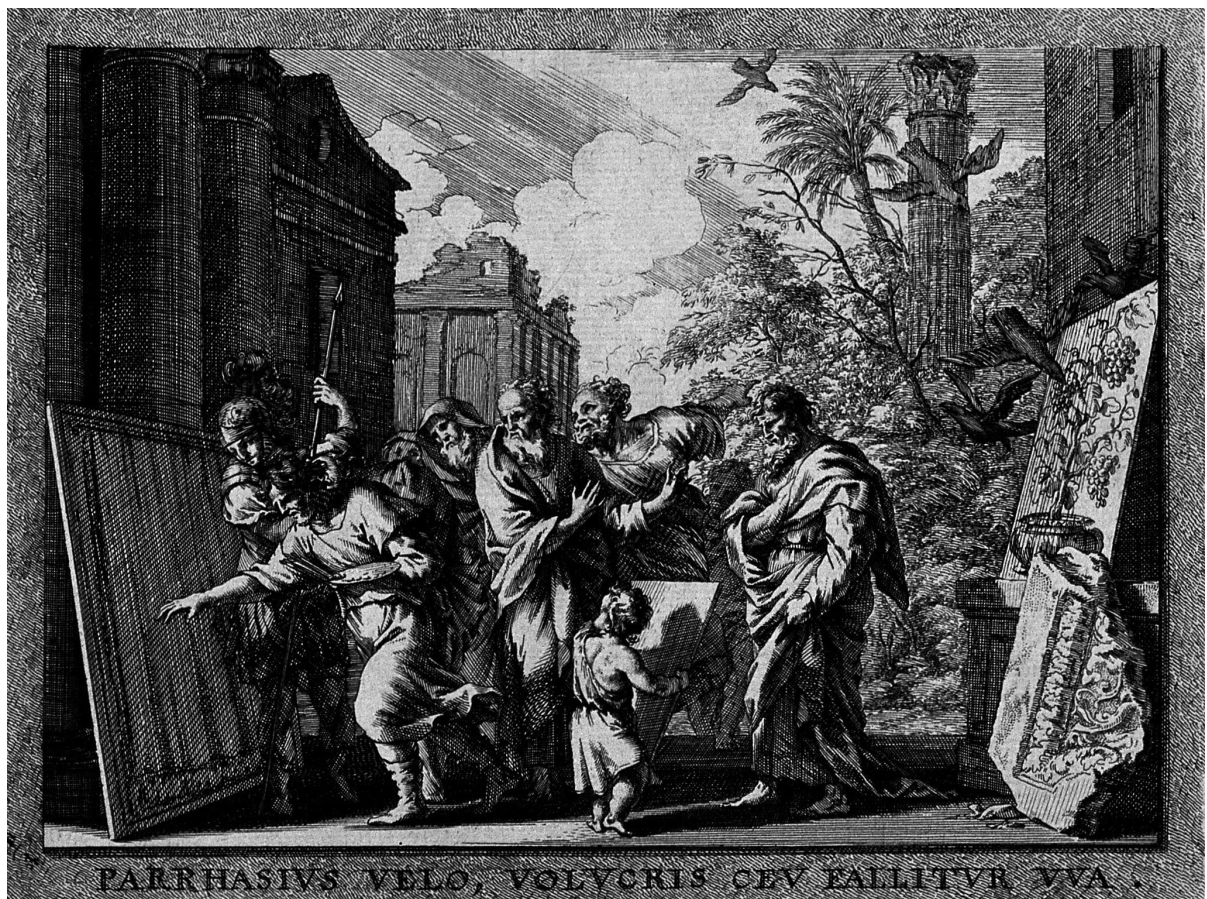

1. Competición entre Zeuxis y Parrasio, con las aves acudiendo a las uvas pintadas en el lado derecho. Grabado de J.J. von Sandrart siguiendo a J. von Sandrart (1606-1688), Wellcome Collection. CC BY

\section{Historias de aves que miran arte}

Las historias de animales reaccionando ante obras de arte están tan ampliamente divulgadas que parecen tener una especie de estatus legendario, y ocupan un territorio en sombras entre realidad y ficción que es inquietantemente similar al problema de la ilusión en sí mismo.

W. J. T. Mitchell, Illusion: Looking at Animals Looking

Se cuenta que este último (Parrasio) compitió con Zeuxis; este presentó unas uvas pintadas con tanto acierto que unos pájaros se habían acercado volando a la escena, y aquél presentó una tela pintada con tanto realismo que Zeuxis, henchido de orgullo por el juicio de los pájaros, se apresuró a quitar al fin la tela para mostrar la pintura, y al darse cuenta de su error, con ingenua vergüenza, concedió la palma a su rival, porque él había engañado a los pájaros, pero Parrasio le había engañado a él, que era artista (Plinio, 1988: 93).

Mi primera historia sobre mirar a aves que miran arte es la de la competición entre los pintores griegos Zeuxis y Parra- sio [1], según la cuenta Plinio el Viejo en su Historia Natural. También es una de las historias de Mitchell, quien la califica como «la anécdota más famosa de animales mirando imágenes» (1995: 334). Recurre a ella tras considerar otras similares compiladas por Leonardo da Vinci -un perro engañado por el retrato de su amo, un mono que tontea ante un cuadro de otro mono, hombres enamorados de imágenes femeninas, o que idolatran otras de divinidades-que utiliza para señalar cómo en dichas historias se despliegan una serie de relaciones de poder entre un yo y un otro, u otros. Así, ese otro u otros caen engañados por la ilusión y la toman por la realidad debido a su inferior (auto)conciencia o control -perro, mono, hombres licenciosos o idólatras foráneos, o las aves en el relato de Plinio- frente a un yo que refuerza su posición y es consciente de la ilusión como imitación de la realidad (Mitchell, 1995: 332-333).

En la historia de Zeuxis y Parrasio, según Mitchell, Plinio estaría siendo algo más benévolo con las aves, puesto que el escritor latino parece tener en gran estima el juicio natural de estas acerca de la calidad ilusionista de las uvas pintadas. Aunque no en una tan alta como la que le merece el 
juicio de Zeuxis, autor de las mismas. O el de Parrasio, que pinta la cortina que confunde al primero, humano y artista (Mitchell, 1995: 336). A diferencia de Mitchell, sin embargo, y dado que me interesan las aves en sí mismas y no como recurso retórico, pienso que en la historia de Plinio está implícito que los pájaros acuden a la pintura porque quieren comer uvas, no porque juzguen la obra de Zeuxis como buena, o artística. La pintura funcionaría de un modo similar, pues, al de cualquier otro cebo o señuelo, incluido el de pesca que dos peces intelectuales consideran poco realista en la viñeta cómica de Roger Bollen con la que Mitchell abre su capítulo. Por lo tanto, a las aves de Plinio no les interesa la pintura, o el arte. Simplemente tienen hambre, y les gustan las uvas.

Asocio esta forma de devaluar, aunque sea sutilmente, el criterio y motivaciones de esas aves con muchas otras reacciones recientes, y recurrentes, con las que me he ido encontrando; reacciones que intentan descartar y desestimar la creatividad, innovación, inteligencia, aprendizaje o habilidades artísticas demostradas por otras aves o animales por no relevantes, o por no ser tales. El argumento detrás de estas reacciones suele ser que los animales hacen lo que sea por la comida, y nada más que por la comida, o por otras recompensas materiales o físicas, incluidas las sexuales. Se asume que la existencia de este tipo de motivaciones detrás de tales acciones, creativas o artísticas, afectaría o modificaría su naturaleza, incluso hasta el punto de invalidarlas. Como si los animales involucrados se los tachara de mecánicos o materialistas, y sus acciones fueran censuradas. De hecho, esto también ocurre con los seres humanos, cuando se menosprecia un trabajo creativo diciendo que se ha hecho por dinero, o se define como proyecto alimenticio un encargo que la autora o autor haya aceptado para poder comer. No parece descabellado asociar esta lectura con Plinio puesto que, como Mitchell señala, este lamenta que las prácticas ilusionistas que habían garantizado la continuidad y grandeza de la nobleza y República romanas hayan sido remplazadas por un énfasis en el oro y el lujo (Mitchell, 1995: 337-338). Los artistas y sus mecenas ya no estarían tan interesados en la pintura, el parecido de los retratos, o el arte en sí, sino en el oro, las materias preciosas, el dinero... o las uvas.

Existen otras historias en la línea de «mirar a aves mirar arte» con enfoques similares al de Plinio. Entre ellas, hay una que se hallaría entre los ecos de las anécdotas clásicas emergidos durante el Renacimiento, y en concreto, en Las vidas de Giorgio Vasari. En el correspondiente pasaje, Vasari elogia una pintura de Girolamo dai Libri [2] en el altar de la iglesia de San Leonardo nel Monte, cerca de Verona:

Hay un árbol pintado por Girolamo en la imagen, y contra él parece descansar la gran silla en la cual la Virgen está sentada. Este árbol, que tiene la apariencia de un lauro, se proyecta considerablemente con sus ramas por encima de la silla, y entre las ramas, que no son muy espesas, se puede ver un cielo tan claro y bello, que el árbol parece de verdad uno vivo, lleno de gracia y de lo más natural. Con mucha frecuencia, por tanto, los pájaros que han entrado a la iglesia por varias aberturas han sido vistos volando hasta este árbol con el fin de posarse sobre él, y particularmente golondrinas, que tienen sus nidos entre las vigas del techo, y del mismo modo sus pequeños. Muchas personas dignas de toda credibilidad declaran que han visto esto, entre ellas Don Giuseppe Mangiuoli de Verona, una persona de vida santa, que ha sido por dos veces General de su Orden y por nada en el mundo afirmaría una cosa que no fuera absolutamente cierta, y también Don Girolamo Volpini, asimismo un veronés, y muchos otros (Vasari, 1912: 50).

De hecho, en su Historia natural Plinio ya recogía una historia similar, asimismo mencionada por Mitchell, en la que unos cuervos habrían tratado de posarse en unas decoraciones pintadas, imitando baldosas o tejas, para unos juegos celebrados por Claudio Pulcro (Mitchell, 1995: 337338). Tanto los cuervos de Plinio como las golondrinas de Vasari son atraídos por un lugar donde posarse, y no por la comida. Pero se volvería a dar una asociación fisiológica, que enfatiza que las aves no han sido tentadas por el arte: solo quieren descansar. A su vez, se manifiestan de nuevo las jerarquías de poder identificadas por Mitchell. Porque quienes están siendo embaucadas son las aves, y los personajes cuyos testimonios corroboran la veracidad de la historia son identificados como ilustres veroneses. Sin embargo, se diría que Vasari insiste demasiado en los méritos de esos testigos. Casi resulta sospechoso, como si temiera que semejante historia resultara difícil de creer para los lectores coetáneos, familiarizados quizás con el comportamiento de las golondrinas dentro de iglesias o amplios edificios oscuros; lectores a los que les podría resultar extraño y poco convin- 
cente visualizar, según lo propuesto por Vasari, a esas aves intentando posarse en una superficie plana solo porque en ella hubiera un árbol pintado.

Sin embargo, desde nuestra posición occidental y ya adentrados en el siglo XXI, lo que más nos puede chocar es imaginar a esas golondrinas del siglo XVI volando y anidando dentro de un edificio histórico, percibido ahora como patrimonio, cuando ahora incluso las expulsamos del exterior de nuestras casas (o urbanizaciones), con el consiguiente impacto negativo en sus poblaciones. Pero es posible que hace unos cien años estas presencias fueran todavía comunes hasta en un museo de arte. $Y$ no un museo cualquiera, puesto que el biólogo Jakob von Uexküll (1864-1944) ubica esta otra historia de «mirar a aves mirar arte» en el interior de las galerías de pintura de los Uffizi:

Observaba yo una vez un tropel de gentes de Cook que eran paseadas por las Galerías de pintura de Florencia. El culto guía se detuvo delante de un cuadro y dijo: "Ya ven ustedes a primera vista, señores míos, que este es un Rafael». «iDiantre! -rezongó un señor viejo-, yo veo simplemente una Madonna con el Niño; eso lo veo muy bien; pero ¿en qué ve él que es de Rafael? Tengo muy buena vista, sin embargo... ¿O es que ese mozo ve cosas invisibles?»

El señor viejo no sabía que él mismo veía cosas invisibles, puesto que [el hecho de que] la mujer del cuadro fuera una Madonna no hubiera podido verlo tampoco un negro. $Y$ que aquel polícromo plano en la pared representara una mujer permanecía totalmente ignorado para la golondrina que cruzaba rauda por la habitación (Uexküll, 1922: 41).

Uexküll delinea con nitidez otra jerarquía, con implicaciones y prejuicios raciales y culturales ${ }^{5}$ : la golondrina pasa volando delante de un cuadro en el que un «negro» solo reconocería una mujer, el señor viejo una Madonna, el culto guía la autoría de Rafael; mientras, el propio Uexküll se sitúa dominando y desentrañando la escena al completo. Aunque hay un cambio significativo con respecto a las historias anteriores, y al resto de las que recopila Mitchell. No se trata de una anécdota en la que «miramos a un ave mirar arte», sino de otra en la que «miramos a un ave que no mira (o no ve) arte». Aquí la golondrina no es engañada por la Madonna de Rafael [3]; según Uexküll, para el pájaro la pintura es solo una superficie policromada a la que no presta atención.

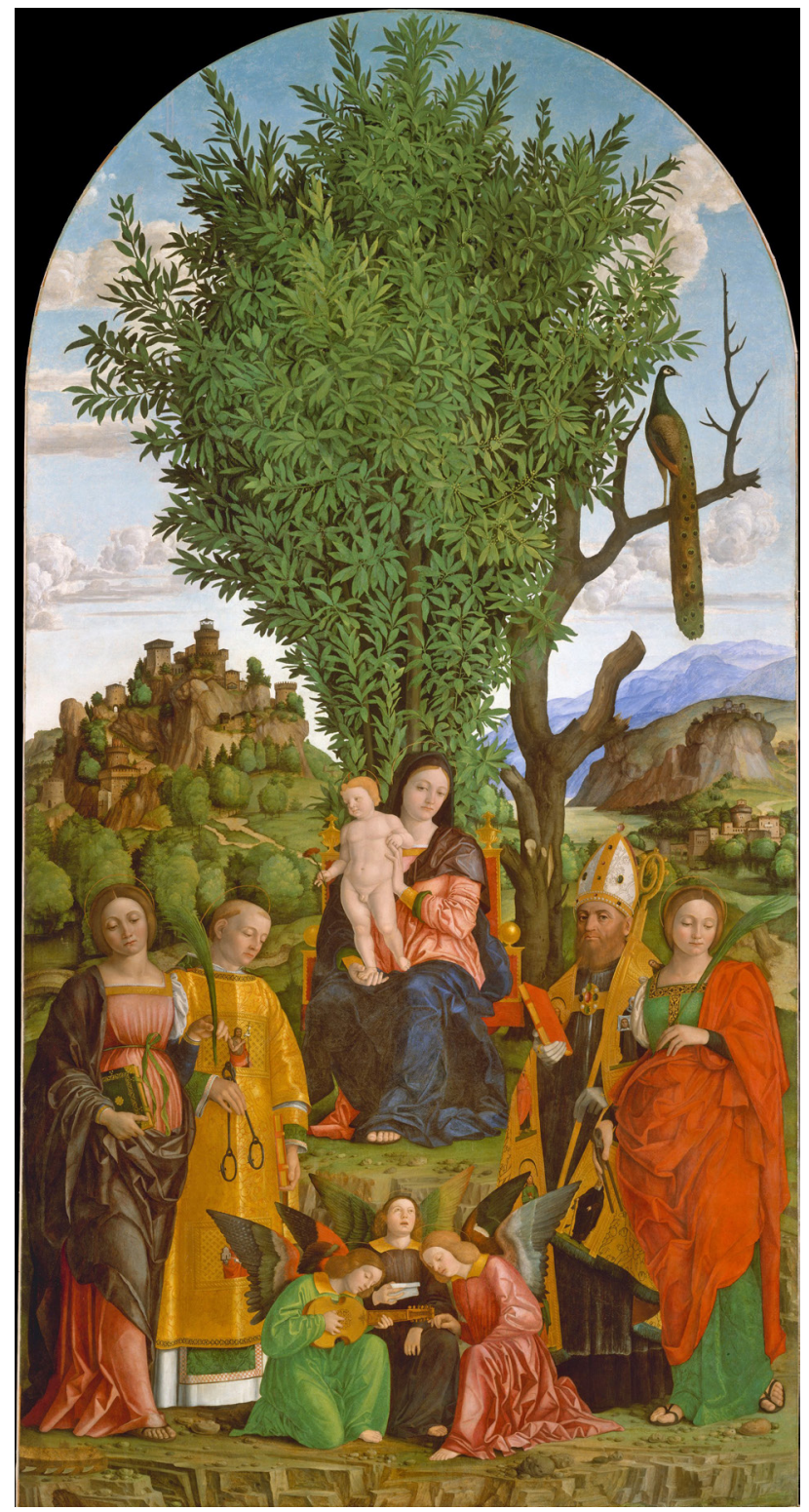

2. Girolamo dai Libri: Madonna y Niño con Santos, ca. 1520. The Metropolitan Museum of Art

En su capítulo, mientras discute las historias de Plinio, Mitchell afirma haber tomado «como axiomático que no hay forma de refutar estas historias: se presentan como hechos, pero podrían muy bien ser folclore», por lo que nuestro único recurso sería "tomar las historias como indecidiblemente verdaderas y falsas, esto es, como ilusiones retóricas que, como las pictóricas, habitan un ámbito dialéctico de ilusionismo, en la frontera entre hecho y ficción» (1995: 337). 


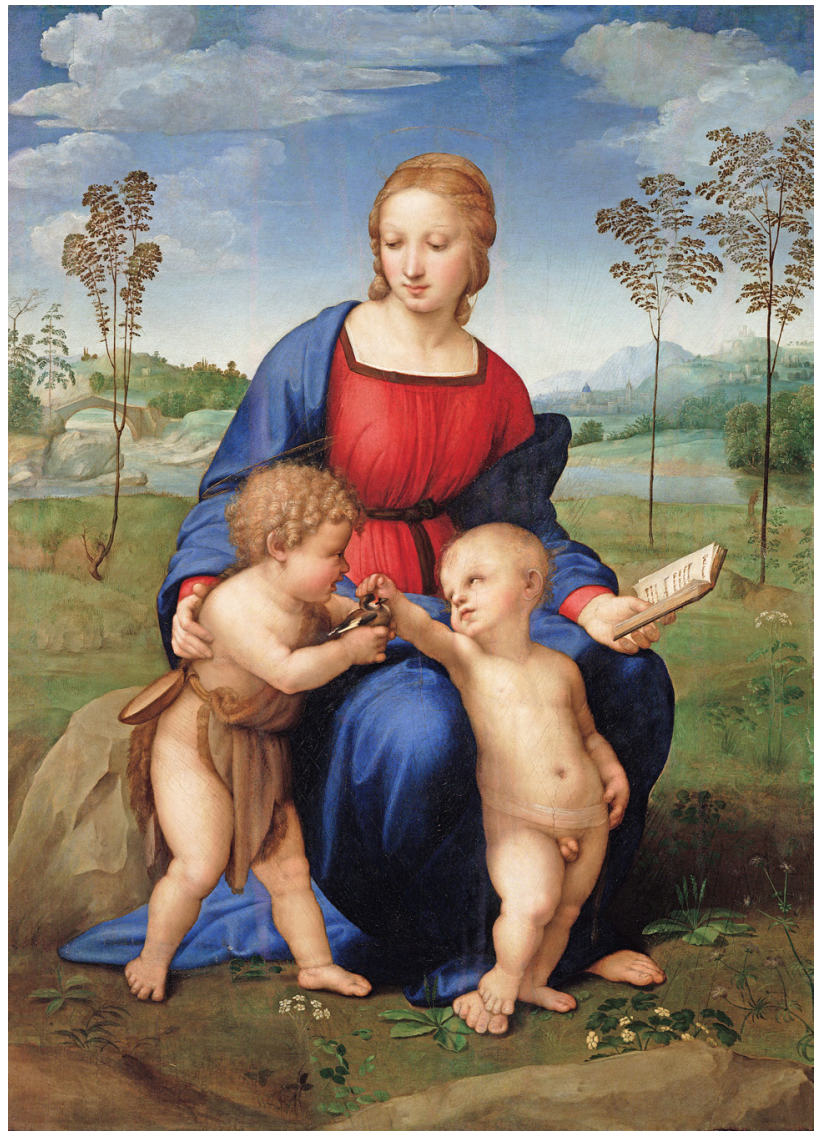

3. Rafael, Madonna del cardellino, ca.1506. Gallerie degli Uffizi

No obstante, Mitchell dice estar convencido de la existencia de científicos behavioristas que estarían estudiando las respuestas animales a ciertas ilusiones pictóricas en ese preciso momento. Pero, al pasar a centrarse en la función de estas historias más que en su veracidad, elige no tener en cuenta los potenciales resultados de esos estudios de cara a sopesar si es posible que haya animales que caigan engañados por una imagen. En este sentido, ya la invocación de testimonios ilustres por parte de Vasari permite vislumbrar que podría haber fricciones en cuanto a cómo escritor y lectores perciben el grado de veracidad de estas anécdotas según, quizás, hacia dónde inclinan la balanza sus experiencias y observaciones cotidianas. Además, diría que mientras Mitchell habla de ilusiones, ilusionismos y sus trucos, este autor está poniendo en práctica uno adicional: el «truco del animal que desaparece» (McHugh, 2009). En teoría, el ensayo del académico estadounidense está repleto de anima- les. Pero cuestiones como su percepción, biología, agencia y preferencias apenas se consideran, y se impone el sopesar su rol en esas historias en términos humanos ${ }^{6}$. Es como si se hubiera agitado una varita en el aire y los animales se hubiesen disuelto entre las líneas, esfumándose dentro del sombrero de copa. Así que, tal y como apunta pero no llega a hacer Mitchell, y como sí han hecho los estudios animales en las últimas décadas, habría que mirar de otro modo y con más atención a las aves (y animales) de estas historias, para buscar soluciones a este rompecabezas.

A grandes rasgos, esto es lo que Uexküll proponía. En algunos de sus escritos nos invita a sumergirnos en los mundos subjetivos y sensoriales de los animales mediante su noción de Umwelt o mundo circundante, que rellena con los conocimientos biológicos disponibles en su época (Uexküll y Kriszat, 1957). De acuerdo con esto, en la anécdota de los Uffizi ${ }^{7}$ modifica el esquema habitual de las historias tipo «mirar a los animales mirar arte» porque tiene en cuenta a la golondrina. Esta no cae en el engaño de la pintura, del arte. Y su perspectiva no es por ello inferior, solo ocurre que tiene unos intereses y percepción que difieren de los humanos. De hecho, Uexküll defendía la relevancia de esta percepción, intereses y subjetividad discrepantes también en animales considerados más simples. Por ejemplo, critica a un colega que había declarado a las moscas domésticas culpables de dejarse devorar por las arañas, y que las describía como animales «tontos e imprevisores», diciendo de este investigador "que su filosofía no ha abandonado el nivel de los cuentos de niños» (Uexküll, 1922: 43). Esto es, el nivel de las historias infantiles en la cuales una mosca personifica la estupidez o glotonería, en términos humanos. Así, si en el relato que alguien hace del comportamiento de una mosca se pueden detectar y desgajar estos añadidos antropomórficos ${ }^{8}$, debería ser posible discutir en qué grado una historia o anécdota sobre «mirar a aves mirar arte» se ajusta a los mundos, intereses y percepciones de los pájaros implicados; empezando por la anécdota de los Uffizi.

Uexküll escribe que la golondrina pasa volando, sin acercarse, por delante de la Madonna, ese «polícromo plano en la pared». En primer lugar, no me resisto a señalar que esta forma de definir un cuadro resulta similar, en su esencia, a la enunciada por el pintor Nabis Maurice Denis en 1890: «Es conveniente recordar que un cuadro -antes de llegar a ser un caballo de guerra, una mujer desnuda o una anécdota 
cualquiera- es esencialmente una superficie plana cubierta con colores organizados de acuerdo con cierto orden» (en Chipp, 1995: 110). Al margen de que se vuelva a situar a una mujer (desnuda, esta vez) junto a un animal (un equino bélico, que suma la muerte al sexo), siendo ambos objetos de la mirada masculina, al igual que Uexküll esta definición elimina el componente ilusionista, en un desplazamiento característico de las vanguardias. En el caso de Uexküll, sus palabras podrían sugerir dos cosas: bien que la golondrina no reconoce lo representado en la imagen, bien que la imagen en sí le es indiferente.

En cuanto a lo primero, ¿es o no posible que una golondrina reconozca lo representado en el cuadro de Rafael, o en cualquier otra imagen? Si examinamos la literatura científica sobre el reconocimiento de objetos en imágenes en aves, no parece haber estudios sobre especies de golondrinas. Sí hay algunos con periquitos, arrendajos azules, diamantes cebra, isabelitas del Japón, gorriones molineros o keas; así como decenas con gallinas y, sobre todo, con palomas (Delius, Emmerton, Hörster, Jäger, y Ostheim, 2000; Wein, Gajdon y Schwing, 2015). Sobre estas últimas, consideradas como criaturas altamente visuales, parece haber evidencias de que sí reconocen ciertas imágenes y las asocian con aquello que representan (Aust \& Huber, 2006, 2010). Sin embargo, en la literatura científica también se expresan dudas acerca de hasta qué punto son concluyentes estas y otras evidencias, y sobre si su interpretación es correcta. Esto debido a la diferente y, en conjunto, superior percepción visual en palomas y aves en general (influencia de las frecuencias ultravioleta que las aves sí aprecian; parpadeo de las pantallas, que los humanos no registramos; tetra- o pentacromatismo y mayor diferenciación de colores en aves; etc.), o al tipo de relevancia científica de estos experimentos (Weisman y Spetch, 2010). Por ello, responder a la pregunta "¿puede una golondrina reconocer a una mujer en un cuadro?» no es sencillo. Entre otras cosas, porque hablamos de una golondrina, no de palomas o gallinas. $Y$ de una pintura, no de una fotografía impresa o en una pantalla.

No obstante creo que si, como en cierto modo hace Mitchell con los escritos de Gombrich (1995: 340-342), sopesamos estos estudios como historias adicionales del tipo «mirar a aves mirar imágenes», nos brindan otro tipo de información, y un contraste valioso. Según los detalles pro-

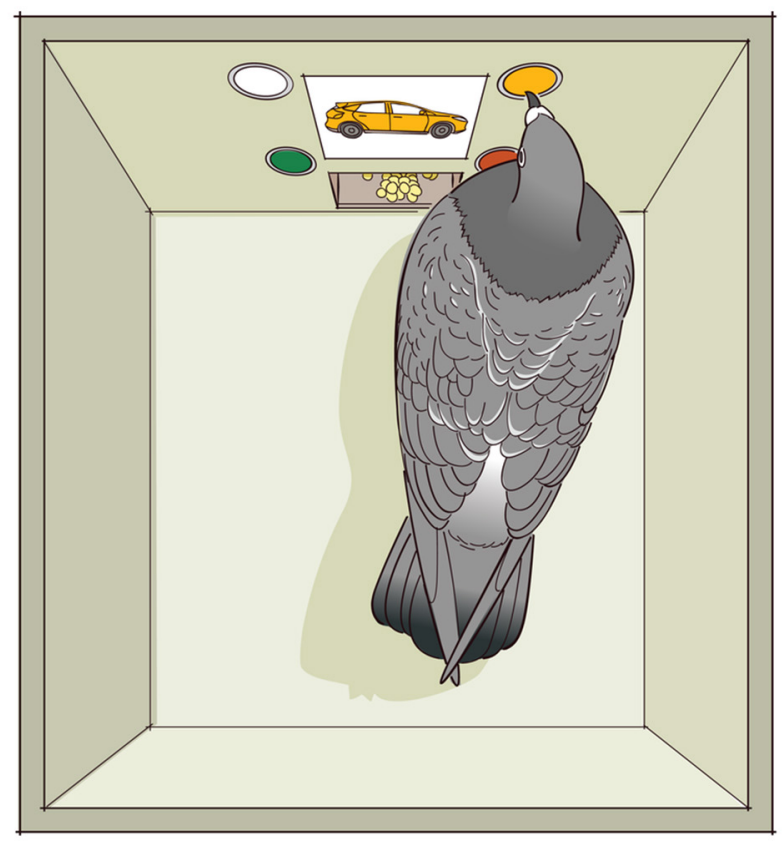

4. Diagrama de una paloma en una caja de Skinner, interaccionando con imágenes. Mark E. Bouton, Universidad de Vermont. CC BY-SA 4.0

porcionados en algunos de los artículos, en líneas generales estas historias irían así [4]:

Se coloca a una paloma (o gallina) en una caja; en concreto, en una caja de Skinner, dentro de la cual podemos mirar a través de su lado o lados transparentes. Se muestran las fotografías o vídeos en una de las paredes de esa caja; a menudo, en una pantalla. Si el pájaro picotea en el área correcta de la pantalla (en origen, se usaban otros mecanismos), ella o él recibe comida como recompensa. Para algunas de estas aves, las recompensas que obtienen durante el entrenamiento y las pruebas es la única alimentación que reciben, y en ocasiones se las mantiene a propósito por debajo de su peso promedio. De este modo, están ansiosas y hambrientas por participar, por interactuar con las imágenes.

En otras palabras, esto significa que los investigadores encierran a las palomas en una caja de manera que no tengan a dónde ir ni nada que las distraiga, y a continuación es como si las sobornaran o chantajearan con comida para que se centren en las imágenes y se interesen por ellas. Ya no sucede, pues, que las aves acudan a las imágenes de comida sino que hay que ofrecerles comida para que hagan caso de las imágenes: el cebo sería la comida, no las imá- 
genes. Además, la mayoría de las palomas tienen que ser entrenadas, previamente, con respecto a la mecánica del experimento y de las imágenes. Todos estos esfuerzos, destinados a que las palomas presten atención a las imágenes, consiguen que resulte difícil concebir a dichas aves acercándose a interactuar con ellas en sus entornos habituales, sea tratando de comer uvas pintadas o de posarse en un árbol ídem. En parte, porque reconocer algo en una imagen no supone, necesariamente, tomarlo por la realidad; pero, por encima de todo, porque nuestras imágenes no parecen ocupar un lugar destacado en el mundo de las palomas. Algo que nuestra experiencia cotidiana parece confirmar, dado que ni vemos ni nos llegan noticias de palomas atacando carteles de variedades de tomates, o intentando posarse en el árbol de un anuncio de carretera.

Si las palomas no expresan un gran interés por las imágenes, diría que el de las golondrinas podría ser todavía menor. Sobre todo porque pasan gran parte de su tiempo volando, y dada nuestra forma de concebir y generar imágenes, ese dinamismo puede resultar contraproducente para apreciarlas. Tiene sentido, entonces, que Uexküll evoque a esa golondrina que atraviesa volando la habitación, y que se limita a ignorar la pintura que cuelga en la pared. Incluso si se diera el caso de que esa golondrina, en ciertas circunstancias y dentro de una caja, pudiera reconocer que esa superficie polícroma representa a una mujer'. La golondrina [5] no es atrapada, pues, en el engaño de la ilusión pictórica; los cuadros con figuras humanas no le interesan, tampoco los de árboles $u$ otras formas pintadas.

Por lo que, según apunta Mitchell, en las historias que miran a aves $\mathrm{o}$ animales mirando imágenes (o arte), desde nuestro lado humano existe esta especie de insistencia en recalcar el interés, la aprobación o incluso el elogio por parte de esos otros animales hacia ciertas cosas que hacemos, imágenes, pinturas, arte. Asimismo, estas historias subrayan nuestro dominio tanto sobre las imágenes como sobre el resto de animales, destacando nuestra maestría en crear unas y nuestro control sobre los otros a través del ilusionismo (Mitchell, 1995: 334). Puesto que, en estos relatos, las imágenes acercan los animales a lo humano, al tiempo que los esclavizan y mantienen a cierta distancia, atrapados entre el error y el engaño (Mitchell, 1995: 339). Por lo tanto, estas anécdotas nos invitan a mirar a esos animales engañados por encima del hombro, reforzados en nuestra supe- rioridad. Y sin embargo, tanto las palomas en cajas como la golondrina de Uexküll cuentan otro tipo de historia. Para que las palomas se ciñan al guion y se centren en las imágenes, es necesario encerrarlas en una caja, haciendo física una esclavización que antes no era tan tangible. Por su parte, la golondrina no muestra ningún interés en imágenes o pinturas, no les presta atención. Estas aves no parecen impresionadas por nuestras imágenes, pinturas o arte, lo que nos podría servir para reevaluar nuestros presuntos méritos bajo una luz distinta. $Y$ de paso, quizás también para admitir que si hay unas criaturas esclavizadas y paralizadas por la adicción a las imágenes somos nosotros mismos, los humanos. Sobre todo en un presente en el que elegimos vivir entre una multiplicidad de pantallas que nos las proporcionan veinticuatro horas al día, y mirando las cuales consumimos una parte considerable de nuestro tiempo. Debido a ello es posible que, en ocasiones, estemos tratando de exorcizar nuestra propia vulnerabilidad frente a las imágenes al imputársela a las aves, $\mathrm{o}$ a otros animales ${ }^{10}$.

\section{Historias de aves que miran, y hacen}

Por otra parte, el que haya aves que muestren indiferencia hacia nuestras imágenes no significa que ese desinterés se extienda a todo lo humano. Sucede que tienen sus propias preferencias, y por lo que parece y a pesar de lo que queremos creer, nuestras imágenes no figuran entre ellas. A continuación, presentaré algunos ejemplos con objetos humanos a los que sí prestan atención, que miran e incluso utilizan de maneras innovadoras. Puesto que, al no estar condicionados por la bidimensionalidad y la carga conceptual que otorgamos a las imágenes y a su contenido, habría un mayor margen para la interacción y la agencia de las aves. Las siguientes historias, pues, seguirán otra fórmula, del tipo «mirar a aves mirar objetos humanos», y «hacer cosas con ellos».

La primera de ellas, localizada en las islas británicas, ha sido presentada como "uno de los casos más ampliamente citados de transmisión cultural en animales» (Lefebvre, 1995). Se trataría de la apertura de las botellas de leche de reparto diario por parte de aves, en su mayoría páridos (carboneros, herrerillos), con el fin de extraer la capa superior de nata. Tras una primera observación en 1921, el comportamiento fue expandiéndose con los años, probablemente, 
gracias a una combinación de descubrimientos e innovaciones independientes y de aprendizaje social, al observarse las aves unas a otras. Todo ello, hasta que el uso humano de las botellas cambió, o se abandonó (Fisher y Hinde, 1949; Lefebvre, 1995). El contraste de esta escaramuza entre culturas (aviar y humana) con la historia de las uvas de Zeuxis es claro. En lugar de resultar esclavizados por lo humano, estos pájaros nos habrían ganado la mano aprovechándose de algo nuestro y demostrando, con cierta creatividad y diversidad de soluciones, que un cierre de aluminio o cartón no era protección suficiente frente a unos pequeños asaltantes emplumados.

Sin embargo, es posible que haya quien estime que este caso no resulta ni elegante ni especialmente creativo o artístico. Puesto que, uvas o nata, de nuevo habría comida implicada. Pero hay otras historias en las que no es así. Como las protagonizadas por algunos ejemplares de pájaros carpinteros norteamericanos, que con el pico realizan sus tamborileos en chimeneas y otros receptáculos o superficies metálicas, como canalones o señales de tráfico (O'Connor, 2004). Como estas actúan como la caja de resonancia de un instrumento y amplifican el sonido y alcance de sus llamadas, parece que les gusta recurrir a ellas para mejorar sus reclamos y comunicación. Suelen hacerlo en primavera, durante unas pocas semanas ligadas a la temporada de apareamiento. No obstante, muchos humanos no terminan de apreciar este comportamiento, y así lo expresan en foros y comentarios, en los que se quejan del estruendo que les despierta todos los días al amanecer (DebiTinCO, 2007; MyBackyardBirding, 2016).

No hay tantos pájaros carpinteros ni chimeneas metálicas en el pueblo en el que resido, pero sí muchos mirlos. Especialmente uno, que elige cuidadosamente la ubicación desde la que canta sus canciones, como si estuviera utilizando los edificios que le rodean a modo de altavoces [6]. Cada primavera despliega un repertorio que incluye cantos de otros pájaros (la llamada de un cernícalo o de un carbonero común como se escucharía a lo lejos), y también sonidos humanos como la alarma o el sonido de cierre de un coche, u otro que podría ser de un móvil ${ }^{11}$. Tanto los pájaros carpinteros como este mirlo se fijan en elementos humanos por los que no sentimos un apego especial, y los emplean de maneras que contrarían nuestras expectativas. Sobre todo, diría, en el caso del mirlo, que en lugar de imitar el equivalente sonoro de las obras

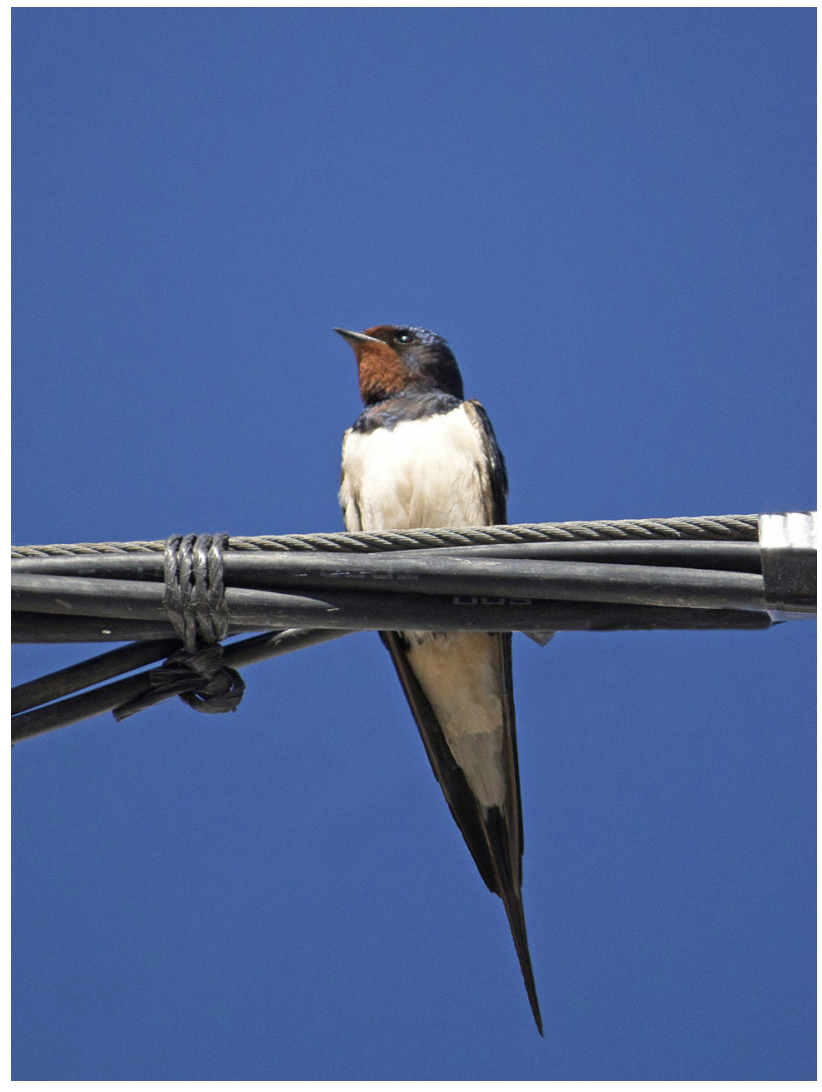

5. Golondrina común (Hirundo rustica), probablemente la especie a la que se refiere Uexküll (fotografía: Ángel Villén)

de arte que se asoman en historias como las de Plinio, Leonardo o Vasari (es decir, canciones, sinfonías, música en general), nos devuelve un retrato de nosotros como especie algo menos adulador, aderezado por los ecos de nuestros ruidos cotidianos; aquéllos que le atraen y que incorpora a sus cantos por motivos que desconocemos.

Solo con los córvidos se podría llenar un libro de ejemplos de interacciones con objetos humanos. Una historia muy llamativa es la de los cuervos japoneses, que reciclan perchas para hacer sus nidos. Las roban, encadenan y combinan con ramas para crear una estructura que, en ocasiones, causa problemas y apagones en las torres eléctricas (“Chubu Electric uses...», 2017). También están muy extendidas las historias que afirman que cuervos, urracas y otros córvidos roban, sobre todo, objetos humanos brillantes. Tal vez porque se sienten atraídos por ellos o, como especula Frans de Waal, porque aves como las urracas se estén re- 


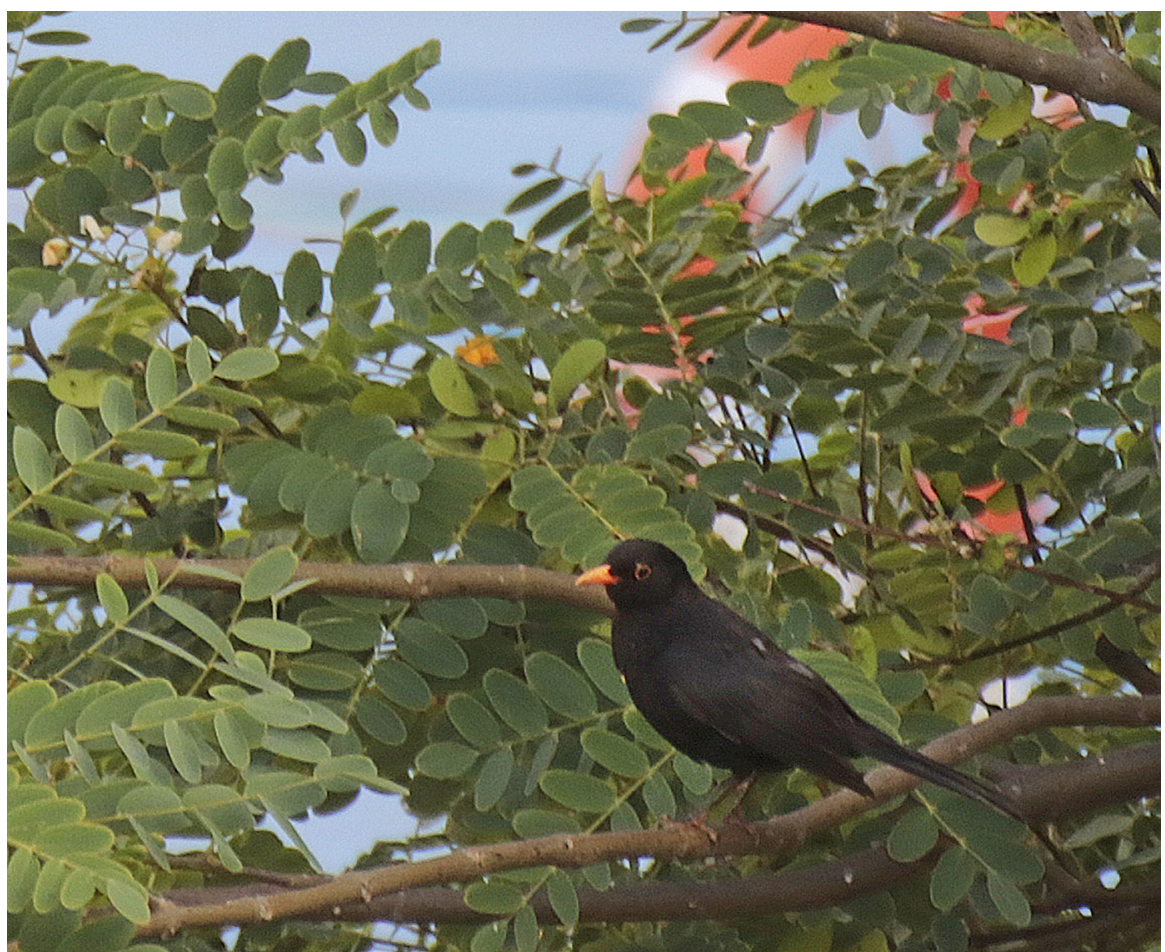

6. El mirlo que, cada año, imita a carboneros comunes y sonidos de coches, entre otros (fotografía: Ángel Villén)

conociendo en sus reflejos, como son capaces de hacer (de Waal, 2008). En cualquier caso, existen muchas historias sobre córvidos y el robo de objetos brillantes, así como personas que afirman que es algo que les ha sucedido. Una joya se esfuma, y tiempo después alguien la localiza dentro de un nido, o en lo alto de un árbol.

De nuevo, como apuntaba Mitchell respecto a los relatos de animales que miran arte (1995: 331), surge la duda de si aquello que miran a aves mirar (y robar) objetos brillantes son hechos, o ficción. Sin embargo, su grado de veracidad parece algo superior. Puesto que además de relatos y testimonios existen fotografías, acompañadas de ciertas comprobaciones. Como en aquella historia que narra cómo, en un lavadero de coches en Virginia (Estados Unidos), desaparecían con regularidad cantidades considerables de monedas de la máquina de pago automático. Y cuando el responsable instaló una cámara de vigilancia, los ladrones resultaron ser unos cuantos estorninos pintos ${ }^{12}$, que parecían trabajar en equipo para extraer las monedas y llevárselas (Mikkelson, 2004).
Curiosamente, y aunque tendamos a olvidarlo, el brillo presente en monedas, joyas y otros es una cualidad relevante de numerosos objetos y materiales a los que, históricamente, hemos asignado valor. Oro, plata, diamantes, gemas y piedras preciosas, en cierta medida compartimos esta predisposición y gusto por lo brillante con algunas aves.

En relación con esto, hay otra historia sobre córvidos que resulta singularmente asombrosa. Todas las mañanas, la niña Gabi Mann y su familia solían alimentar a los cuervos del vecindario en el jardín de su casa, y en cierto momento se dieron cuenta de que las aves dejaban cosas tras de sí, que la familia identificó como regalos para ellos. Comenzaron entonces a recoger y archivar lo que los cuervos seleccionaban y traían (Sewall, 2015). La mayoría de estos objetos están hechos por humanos, a excepción de algún hueso, semilla o piedrecitas. $Y$ aunque sus características son variadas, unas cuantas son compartidas por varios o bastantes de ellos, que tienden a ser brillantes, redondeados, lisos, pequeños, pulidos, de colores suaves y-o articulados, una combinación de palabras que recuerda a la recapitulación que el político 
y filósofo Edmund Burke (1729-1797) hizo sobre las cualidades de lo bello:

En conjunto, las cualidades de la belleza, como cualidades meramente sensibles, son las siguientes: Primero, ser comparativamente pequeña. En segundo lugar, ser suave. En tercero, tener variedad en la dirección de las partes; pero, en cuarto, tener esas partes no angulares, sino como si estuvieran fundidas unas en otras. En quinto lugar, ser de un marco delicado, sin ninguna apariencia o fortaleza destacable. En sexto, tener sus colores claros y brillantes, pero no demasiado fuertes y resplandecientes. En séptimo lugar, o si tuviera algún color resplandeciente, tenerlo diversificado con otros (Burke, 1757: 103-104).

Estos cuervos, pues, seleccionaban y dejaban tras de sí, quizás a modo de ofrenda, pequeños objetos que habían llamado su atención: cuentas, botones, pendientes, pedacitos de vidrio y de plástico de colores, dijes, colgantes, tuercas y otras piezas metálicas. Aunque en esta historia vuelva a haber comida implicada -la que proporcionaba la familia- el comportamiento en sí de las aves no es un requisito imprescindible para recibirla, sino que las ofrendas se producen como un añadido espontáneo, incluso puede que como una comunicación o intercambio social entre especies. Además, a diferencia de la historia de las uvas de Zeuxis y similares, en esta ocasión se diría que las aves acuden a recoger y transportan esos objetos por sus propias preferencias, porque los aprecian en sí y no porque hayan sido engañadas para confundirlos con otra cosa. $Y$ son estas preferencias las que, en parte, resuenan con las palabras escogidas por Burke para delimitar la belleza. Esto es, puede que los cuervos (y quizás también otras aves) no compartan con nosotros el mismo tipo de atracción hacia las imágenes o su ilusionismo. Pero podrían estar manifestando ciertas preferencias estéticas que, en algunos de sus rasgos, se alinean con otros que se han reconocido y definido en la expresión de las nuestras.

Si en la historia de la niña y de los cuervos que le traen regalos se esboza la cuestión de las preferencias estéticas de estas aves, el caso de los pájaros pergoleros o bowerbirds profundizaría más al respecto. Esta familia de aves (Ptilonorhynchidae) está formada por una veintena de especies que se distribuyen entre Australia y Papúa-Nueva Guinea
(Frith \& Frith, 2008; Frith, Frith, \& Barnes, 2004). Los machos de la mayoría de estas especies utilizan ramas y otros materiales para elaborar unas estructuras complejas, que no nidos, conocidas como bowers (pérgolas), que después decoran con colecciones de objetos (flores, élitros de escarabajo, semillas, frutos, hojas, alas de mariposa, hongos, conchas de caracol, plumas de ave del paraíso, huesecillos, gravilla, plásticos, cristales y otros objetos de origen humano, etc.) que organizan y componen en función de su color, brillo, forma, tamaño, rareza... Las hembras son las que juzgan estéticamente el resultado conjunto, y eligen así pérgola, y pareja.

Cada una de las especies de pergolero construye un tipo específico de pérgola, sea en forma de avenida o alrededor de un poste o postes centrales. Pero esto no significa que todas las pérgolas de una misma especie sean idénticas. Tomemos, por ejemplo, los pergoleros de Vogelkop (Amblyornis inornata), que elaboran una pérgola de tipo central, a modo de un pabellón de jardín, en cuyo interior y alrededores disponen diversas y variadas decoraciones. Se ha llegado a señalar que diferentes poblaciones de esta especie habrían desarrollado distintos estilos artísticos, con más o menos elementos, favoreciendo ciertas combinaciones de colores y composiciones (Diamond, 1986). El hecho de perfeccionar y de juzgar estos estilos se aprendería y transmitiría culturalmente. Asimismo, cada individuo tendría preferencias propias, y cada macho ha de explorar numerosos parámetros para realizar y decorar una buena pérgola, como su orientación, juegos de luces y sombras a lo largo del día, combinación de colores, composición y variedad de elementos. Y, sobre todo, ha de atender a cómo funcionaría el conjunto como escenario de las coreografías y cantos del ritual de cortejo, como plataforma viva que modularía tanto movimientos como miradas. Los machos de algunas de estas especies escogen una de las decoraciones para ofrecérsela a la hembra con el pico como muestra. Los de otras (como el pergolero de MacGregor, Amblyornis macgregoriae) interponen el poste central de su pérgola entre ellos y las hembras que los visitan, girando alrededor del mismo mientras permanecen fuera del alcance de su mirada y emiten sonidos e imitaciones. Hasta que, repentinamente, emergen y durante un instante le muestran algún efecto de su plumaje, para luego volver a desaparecer (Sielmann, 1967). De estas y otras maneras, en las pérgolas se entrecruzan sonidos, 


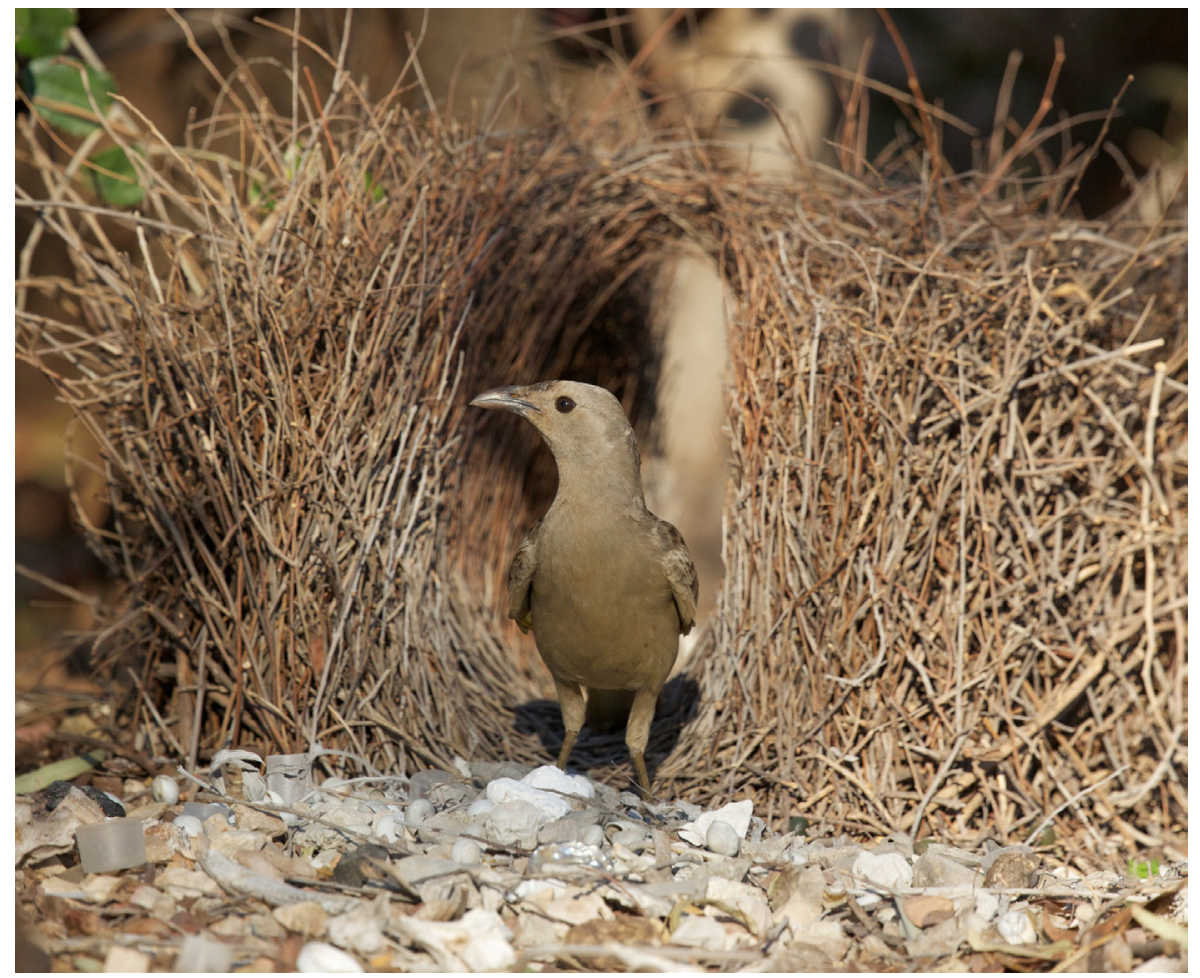

7. Pergolero grande en su pérgola. Fotografía de Julie Burgher. CC BY-NC-ND 2.0

miradas, y movimientos, y además, son espacios vivos y en continuo cambio, puesto que los pergoleros utilizan musgo para tapizarlos, o reemplazan los materiales orgánicos que se van estropeando.

Para concluir, una última historia, que miraría a aves que miran, hacen y juzgan arte. Aves que parecen sopesar, a su vez, la mirada de otras aves que miran lo que han compuesto [7]:

Los machos de pergolero grande (Ptilonorhynchus nuchalis) construyen pérgolas que comprenden dos densas paredes paralelas de ramitas y un suelo que crean una avenida de hasta $1 \mathrm{~m}$. de largo. Cada extremo de la avenida se abre sobre un área de exhibición ${ }^{13}$, donde una superficie de terreno es despejada y cubierta con de decenas a cientos de objetos grises y blancos como piedras, conchas y huesos [...]. Estos objetos proporcionan un fondo contra el que el macho presenta decoraciones de colores durante la exhibición. Los objetos no son colocados aleatoriamente sobre el área de exhibición, sino que son ordenados por tamaño de modo que los objetos más pequeños estén más cerca de la avenida y los objetos más grandes estén más alejados (es decir, según un gradiente positivo de tamaño-distancia, en lo sucesivo denominado 'gradiente'). Cuando una hembra ve esa área desde dentro de la avenida durante la exhibición del macho, esta distribución forma un mosaico de ángulos visuales uniforme que crea una ilusión de perspectiva forzada (Kelley \& Endler, 2017).

Debido a esta perspectiva forzada, el campo resultante se percibiría como más uniforme, lo que influiría sobre cómo ve la hembra los movimientos del macho y el conjunto de la colección de objetos. Algunos pergoleros, pues, serían «ilusionistas con cerebro de pájaro ${ }^{14}$ (Anderson, 2012). Esto es, aves que practicarían un tipo concreto de ilusionismo en el que apelarían a la percepción de otras aves manipulando (con el pico) objetos para crear ilusiones sensoriales con un fin expresivo, en procesos en los que la transmisión cultural tiene un rol significativo. Por lo que este caso o historia termina de desbaratar los ejes que dibujan las tesis con las que 


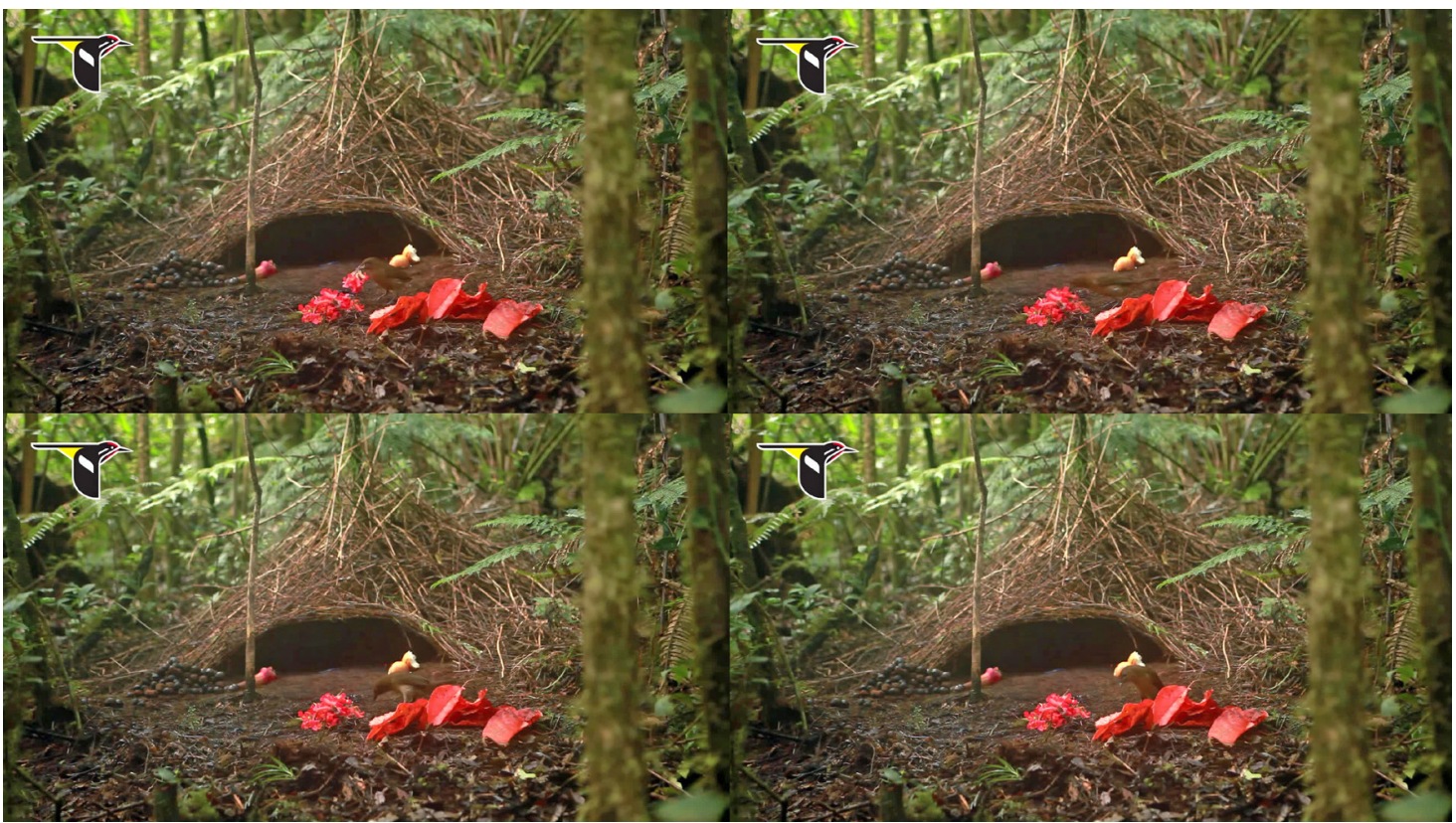

8. El paso atrás del pergolero de Vogelkop. Capturas de un vídeo del Cornell Lab of Ornithology, 2015

Mitchell inicia su texto, en las que se alinea la ilusión con lo animal, y lo natural-biológico, y el ilusionismo con lo humano y la cultura. Además, el ilusionismo de los pergoleros no concerniría a las imágenes miméticas que llenan nuestros mundos primates y humanos, y que nos obsesionan hasta el punto de querer extender su influjo a otras especies. Más bien, estaría más sensorialmente anclado en el espacio y en lo corporal, en lugar de distanciado y abstraído de esas dimensiones.

A su vez, el ilusionismo de estas aves expone complejidades perceptivas y cognitivas capaces de crear gradientes, y «teatros de la perspectiva» (Endler, Endler, \& Doerr, 2010) dirigidos a otros sujetos. Como también fondos neutros (blancos, grises) sobre los que se destacan objetos de otros colores, o que contrastan con el cuerpo y movimientos de estas aves. Complejidades que, en pergoleros como los satinados (Ptilonorhynchus violaceus), darían lugar a un comportamiento que recuerda a lo que conocemos como pintar, pues supone alterar el color de las paredes de la pérgola mediante la aplicación de una mezcla viscosa utilizando, como pincel y herramienta, una especie de esponja de materia vegetal machacada (Frith \& Frith, 2008: 140).
Así, cuando un pergolero de Vogelkop lleva nuevas flores a su pérgola, las coloca en el lugar que ha escogido para una de las pequeñas pilas monocromas que la decoran, compone esas flores con cuidado, y después da un paso, o saltito, hacia atrás, y mira con atención el resultado [8], es difícil no pensar en un artista, pintor o escultor, valorando el efecto de su obra sobre su percepción y la de otras aves (Cornell Lab of Ornithology, 2015). Y aunque un pergolero de Vogelkop no sea un artista humano, como ave artista construye y decora una estructura para otras aves, componiendo con objetos, luces y colores, movimientos y sonidos. Por las divergencias entre nuestras percepciones, y mundos subjetivos, mientras los pergoleros de Vogelkop miran, se mueven, cantan y se aparean en torno a sus pérgolas, nosotros las reproducimos en imágenes, sea fotografiándolas o enmarcándolas como pinturas ${ }^{15}$. Y aunque sea en esta disyuntiva donde concluye este texto, quizás sería donde tendría que comenzar. En concreto, en el punto en el que los humanos no serían los únicos animales que miran cómo otros miran lo que miran y crean, y quizás desde donde tendríamos que aprender, una vez más, a mirar a los pergoleros en particular, y a las aves y demás animales en general. 


\section{Notas}

1 Este artículo fue realizado como investigadora postdoctoral Juan de la Cierva Formación del Min. de Ciencia, Innovación y Universidades, y estando ligada a los proyectos de investigación Prácticas de subjetividad en las artes contemporáneas (HAR2016-75662-P), y Arte y cognición corporal en los procesos de creación (HAR2017-85485-P).

2 A no ser que se indique lo contrario, todas las traducciones son de la autora.

3 Expresión tomada de: https://www.seo.org/ave/golondrina-daurica/

4 Presenté una primera versión de este texto, una ampliación sobre algunos puntos que ya había tocado en mi tesis doctoral (Cortés, 2016), en el Seminario Looking at Animals Looking: Illusion, Imitation, Zoopoetics, organizado por Kári Driscoll en el encuentro anual de la American Comparative Literature Association, ACLA (Universidad de Utrecht, julio 2017). Y volví a retomarlo para una conferencia impartida, gracias a Luis Vives, en el Máster de Cultura Visual e Historia del Arte de la Universidad de Valencia, mayo de 2019

5 Incluso de género, porque el objeto mirado es una mujer pintada y los sujetos que miran son masculinos. Excepto, quizás, por la golondrina, de la que ignoramos si es macho o hembra.

6 De hecho, Mitchell califica como ilusión definitiva el que la psicología experimental crea poder resolver la cuestión de la percepción de ilusiones mediante una teoría basada en experimentos con otros animales (1995: 339).

7 Es llamativo lo centrales que son los componentes del relato para la historia del arte occidental: los Uffizi, Florencia, Rafael, y el asunto, una Madonna que podría ser la conocida como Madonna del cardellino o jilguero por el ave que aparece [3], cerrando el círculo en cuanto a estas se refiere.

8 Teniendo cuidado, como ha sido una inercia dominante en el ámbito científico, de no pasar del antropomorfismo a la antroponegación, que negaría ciertas capacidades a otros animales por haber sido etiquetadas como exclusivamente humanas (de Waal, 2007: 89-98).

9 O de que una paloma llegara a categorizar esa pintura como renacentista u obra de Rafael, dadas las evidencias de que estas aves pueden diferenciar estilos pictóricos (Watanabe, 2001; Watanabe, Sakamoto, \& Wakita, 1995).

10 Como por ejemplo, en anuncios de 2011 en los que una gallina o una niña tomaban por reales, respectivamente, los huevos o el pez payaso que veían en la pantalla de un móvil Samsung. Cuando el principal engaño residiría en que nos convenciésemos de la fidelidad y calidad del aparato por dichos anuncios.

11 De hecho, el mirlo y su repertorio me han acompañado durante la redacción de este artículo.

12 Los estorninos no son córvidos, aunque su inteligencia y habilidades vocales son notables.

13 Display court.

14 «Bird-brained illusionists», juego de palabras en el que «bird brain» sería similar a nuestro "cerebro de chorlito».

15 Como hace la pintora Mary Jo McConnell, que pinta las pérgolas y considera que los pergoleros son también pintores, por su uso del color y la luz (PBS, 2009).

\section{Bibliografía}

ANDERSON, Barton L. (2012), «Bird-brained illusionists», Science, vol. 335, n. 6066, pp. 292-293.

AUST, Ulrike y HUBER, Ludwig (2006), «Picture-object recognition in pigeons: Evidence of representational insight in a visual categorization task using a complementary information procedure», Journal of Experimental Psychology: Animal Behavior Processes, vol. 32, n. $^{\circ} 2$, pp. 190-195.

- (2010), «Representational insight in pigeons: comparing subjects with and without real-life experience», Animal Cognition, vol. 13, n. ${ }^{\circ}$, pp. 207-218.

BERGER, John (1991), «Why look at animals?», About looking, Vintage International, Nueva York, pp. 2-28.

BURKE, Edmund (1757), A Philosophical Inquiry into the Origin of Our Ideas of The Sublime and Beautiful With Several Other Additions, R. and J. Dodsley, Londres.

CHIPP, Herschel B. (1995), Teorías del arte contemporáneo: fuentes artísticas y opiniones críticas, Akal, Madrid.

«Chubu Electric uses artificial nests so crows don’t build their own on power towers» (2017), The Japan Times Online, 22 de mayo. En: <https://www.japantimes.co.jp/news/2017/05/22/national/chubu-electric-uses-artificial-nests-crows-dont-build-power-towers/> (fecha de consulta: 06-07-2019).

CORNELL LAB OF ORNITHOLOGY (2015), He Delivers Flowers: Vogelkop Bowerbird [en línea]. En: <https://www.youtube.com/watch?v=_ Dq437HuhO0> (fecha de consulta: 06-07-2019).

CORTÉS ZULUETA, Concepción (2016), Fundamentos biológicos de la creación: Animales en el arte y arte animal, Universidad Autónoma de Madrid. 
DAWKINS, Marian Stamp (1993), Through Our Eyes Only? The Search for Animal Consciousness, W. H. Freeman, Spektrum; Oxford, Nueva York.

DE WAAL, Frans (2007), Primates y filósofos: la evolución de la moral del simio al hombre, Paidós, Barcelona.

- (2008), «The Thief in the Mirror», PLoS Biology, vol. 6, n. ${ }^{\circ}$ 8, p. e201.

DEBITINCO (2007), «Woodpecker?? Attacking the Chimney Flashing», Houzz [en línea]. En: <http://www.houzz.com/discussions/2134041/ woodpecker-attacking-the-chimney-flashing > (fecha de consulta: 22-06-2019).

DELIUS, Juan, EMMERTON, Jacky, HÖRSTER, Wolfgang, JÄGER, Ralph y OSTHEIM, Joachim (2000), «Picture-object recognition in pigeons», en FAGOT, Joël (ed.), Picture perception in animals, Psychology Press, Hove, pp. 1-35.

DIAMOND, Jared (1986), «Animal art: Variation in bower decorating style among male bowerbirds Amblyornis inornatus», Proceedings of the National Academy of Sciences, vol. 83, n. ${ }^{\circ}$, pp. 3042-3046.

ENDLER, John A., ENDLER, Lorna C. y DOERR, Natalie R. (2010), «Great Bowerbirds Create Theaters with Forced Perspective When Seen by Their Audience», Current Biology, vol. 20, n. ${ }^{\circ}$ 18, pp. 1679-1684.

FISHER, James y HINDE, Robert A. (1949), «The opening of milk bottles by birds», British Birds, vol. 42, pp. 347-357.

FRITH, Clifford B. y FRITH, Dawn W. (2008), Bowerbirds: Nature, Art and History, Frith \& Frith, Malanda, Queensland.

FRITH, Clifford B., FRITH, Dawn W. y BARNES, Eustace (2004), The bowerbirds: Ptilonorhychidae, Oxford University Press, Oxford, Nueva York.

KALOF, Linda (2007), Looking at animals in human history, Reaktion Books, Londres.

KELLEY, Laura A. y ENDLER, John A. (2017), "How do great bowerbirds construct perspective illusions?", Royal Society Open Science, vol. 4, n. ${ }^{\circ} 1$, p. 160661.

LEFEBVRE, Louis (1995), «The opening of milk bottles by birds: Evidence for accelerating learning rates, but against the wave-of-advance model of cultural transmission", Behavioural Processes, vol. 34, n. ${ }^{\circ}$ 1, pp. 43-53.

MARLER, Peter (1996), «Social Cognition: Are Primates Smarter than Birds?», en NOLAN, Val y KETTERSON, Ellen D. (eds.), Current Ornithology, Springer, Boston, pp. 1-32.

MCHUGH, Susan (2009), "Animal farm's lessons for literary (and) animal studies», Humanimalia: A Journal of Human/Animal Interface Studies, vol. 1, n. ${ }^{\circ}$ 1. En: <https://www.depauw.edu/humanimalia/issue01/mchugh.html> (fecha de consulta: 24-06-2019).

MIKKELSON, David (2004), «Change Is in the Air! Do photographs show thieving birds stealing quarters from a car wash?», Snopes [en línea]. En: <https://www.snopes.com/fact-check/change-is-in-the-air/> (fecha de consulta: 24-06-2019).

MITCHELL, W. J. T. (1995), «llusion: Looking at animals looking», en Picture Theory: Essays on Verbal and Visual Representation, Univ. of Chicago Press, Chicago, pp. 329-344.

MYBACKYARDBIRDING (2016), «Northern Flicker Woodpecker Pecking a Metal Chimney Cap» [en línea]. En: <https://www.youtube.com/ watch?v=GrEbH3MwHSA> (fecha de consulta: 22-06-2019).

O'CONNOR, Mike (2004), «Flickers on Chimnies», The Cape Codder, 2 de abril. En: <http://www.birdwatchersgeneralstore.com/chimney. $\mathrm{htm}>$ (fecha de consulta: 24-06-2019).

PBS (2009), FRONTLINE/World | West Papua: The Clever One | PBS [en línea]. En: <https://www.youtube.com/watch?v=zuqqGYr2a5Y> (fecha de consulta: 07-07-2019).

PLINIO, EI Viejo (1988), Textos de historia del arte, Visor, Madrid.

SEWALL, Katy (2015), «The girl who gets gifts from birds», BBC News Magazine, 25 de febrero. En: <https://www.bbc.com/news/magazine-31604026> (fecha de consulta: 20-06-2019).

SIELMANN, Heinz (1967), «Amblyornis macgregoriae (Ptilonorhynchidae) - Behängen des 'Maibaumes' und Balz», [en línea]. En: <https:// av.tib.eu/media/16050> (fecha de consulta: 02-07-2019).

UEXKÜLL, Jakob von (1922), Ideas para una concepción biológica del mundo, Calpe, Madrid.

UEXKÜLL, Jakob von y KRISZAT, Georg (1957), «A Stroll Through the Worlds of Animals and Men. A Picture Book of Invisible World», en SCHILLER, Claire H. (ed.), Instinctive Behavior. The Development of a Modern Concept, International University Press, Nueva York, pp. $5-80$ 
VASARI, Giorgio (1912), Lives of the most eminent painters, sculptors \& architects, vol. VI, Macmillan and Co. Ld., Philip Lee Warner [for] The Medici Society, Londres.

WATANABE, Shigeru (2001), «Van Gogh, Chagall and pigeons: picture discrimination in pigeons and humans», Animal Cognition, vol. 4, n. ${ }^{\circ}$ 3, pp. 147-151.

WATANABE, Shigeru, SAKAMOTO, Junko y WAKITA, Masumi (1995), «Pigeons' discrimination of paintings by Monet and Picasso», Journal of the Experimental Analysis of Behavior, vol. 63, n. ${ }^{\circ}$ 2, pp. 165-174.

WEIN, Amelia, GAJDON, Gyula K. y SCHWING, Raoul (2015), «Picture - Object Recognition in Kea (Nestor notabilis )», Ethology, vol. 121, n. ${ }^{\circ} 11$, pp. 1059-1070.

WEISMAN, Ronald G. y SPETCH, Marcia L. (2010), «Determining When Birds Perceive Correspondence Between Pictures and Objects: A Critique», Comparative Cognition \& Behavior Reviews, vol. 5, pp. 117-131. 